\title{
Surgery for metastatic tumors of the pancreas
}

\author{
Taisuke Yagi', Daisuke Hashimoto', Katsunobu Taki', Kensuke Yamamura', Akira Chikamoto', Masaki Ohmuraya², \\ Toru Beppu ${ }^{1}$ and Hideo Baba ${ }^{1 *}$ (i)
}

\begin{abstract}
Metastatic lesion of the pancreas originated from other organs is uncommon. The aim of this report was to evaluate the outcome of surgery in patients with isolated metastases to the pancreas. Nine patients underwent pancreatic resection for metastatic malignant disease from 2000 to 2015 at the Department of Gastroenterological Surgery of the Kumamoto University Hospital. The primary lesion was renal cell carcinoma in 7 cases, colon cancer in 1 and malignant melanoma in 1. The median interval from the initial operation to pancreatic resection was 138 months. Operative procedure was distal pancreatectomy in 6 cases, pancreaticoduodenectomy in 2 and total pancreatectomy in 1. Two patients with renal cell carcinoma and 1 patient with malignant melanoma died 131, 108, and 4 months after the pancreatic resection, respectively. Other 6 patients have survived until now with 23.5 months of observation periods after pancreatic resection. In conclusion, pancreatic metastasis can develop years after the treatment of primary lesion. Pancreatic resection can achieved long-term survival, at least in the patients who had primary renal carcinoma.
\end{abstract}

Keywords: Metastasis, Pancreas, Operation

\section{Background}

Most pancreatic tumors are primary pancreatic adenocarcinoma. However, metastatic pancreatic tumor can be developed from renal cell cancer, lung, breast, colon, or skin tumors [1-7]. Metastasis to the pancreas is rare, accounts for less than $2 \%$ of all pancreatic malignancies [3, 4, 8-11] and can be generally developed synchronous or metachronous and single or multiple. In addition, a previous large autopsy series indicated that the prevalence of pancreatic metastases was 6 to 11\%, and renal cell carcinoma was the most common primary tumor to cause metastatic pancreatic tumors [12].

Experience with resections of pancreas for the isolated metastatic lesions is very limited $[3,6-8,10,11,13,14]$, because metastatic disease to the pancreas is considered to exist commonly with metastasis to other organs such as the liver and lung [1]. As a result, the value of surgical treatment to the metastasis to the pancreas is unclear, and there are no guidelines or recommended strategies regarding the appropriate management of such lesions.

\footnotetext{
* Correspondence: hdobaba@kumamoto-u.ac.jp

'Department of Gastroenterological Surgery, Kumamoto University Graduate School of Medical Sciences, 1-1-1 Honjo, Kumamoto City 860-8556, Japan Full list of author information is available at the end of the article
}

The aim of this report was to evaluate the outcome of surgery in patients with metastases to the pancreas.

\section{Case presentation \\ Patients' characteristics, primary tumors, and other metastasis before pancreatic metastasis}

Nine patients underwent pancreatic resection for metastatic malignant disease from 2000 to 2015 at the Department of Gastroenterological Surgery of the Kumamoto University Hospital. The patients included 5 males and 4 females, with a median age of 66 years (range, 52-83) at the pancreatic surgery (Table 1). The primary lesion, clear cell renal cell carcinoma (RCC) (right kidney in 3, left in 3, and bilateral in 1), 1 rectal cancer (tubular adenocarcinoma), and 1 oral malignant melanoma (MM), was resected in all cases.

Before the emergence of the pancreatic metastasis, 2 patients experienced metastasis of the other organs (Table 1). Bilateral multiple lung metastasis from RCC was developed in case no. 5, 10 months before the pancreatic metastasis. It was treated by axitinib, followed by sunitinib, and archived partial response (PR). In this case, the lung metastases were well-controlled by chemotherapy. However, pancreatic metastasis was growing, and so distal pancreatectomy was 
Table 1 Patients' characteristics, primary tumors, and other metastasis before pancreatic metastasis

\begin{tabular}{|c|c|c|c|c|c|c|}
\hline \multirow{2}{*}{$\begin{array}{l}\text { Case } \\
\text { no. }\end{array}$} & \multirow{2}{*}{$\begin{array}{l}\text { Age at the } \\
\text { pancreatic } \\
\text { surgery/ } \\
\text { gender }\end{array}$} & \multicolumn{3}{|l|}{ Primary tumors } & \multicolumn{2}{|c|}{ Other metastasis before pancreatic metastasis } \\
\hline & & Location & Treatment & Histology & Location & Treatment \\
\hline 1 & $61 / F$ & Left kidney & Resection & Clear cell RCC & - & - \\
\hline 2 & $52 / \mathrm{M}$ & Bilateral kidney & Resection & Clear cell RCC & - & - \\
\hline 3 & $67 / F$ & Left kidney & Resection & Clear cell RCC & - & - \\
\hline 4 & $83 / \mathrm{M}$ & Right kidney & Resection & Clear cell RCC & - & - \\
\hline 5 & $66 / M$ & Left kidney & Resection & Clear cell RCC & Bilateral lung & Axitinib $\rightarrow$ Sunitinib \\
\hline 6 & $69 / F$ & Right kidney & Resection & Clear cell RCC & - & - \\
\hline 7 & $55 / F$ & Right kidney & Resection & Clear cell RCC & & \\
\hline 8 & $72 / \mathrm{M}$ & Rectum & Resection & Tubular adenocarcinoma & Right lung & Resection \\
\hline 9 & $55 / M$ & Oral cavity & Resection & Malignant melanoma & - & - \\
\hline
\end{tabular}

RCC renal cell carcinoma

performed. A solitary right lung metastasis from rectal cancer in case no. 7 was resected 76 months before the pancreatic metastasis.

\section{Characteristics of the pancreatic metastasis and results of the pancreatic surgery}

The median interval from the initial surgery to the emergence of the pancreatic metastasis of the whole cases was 138 months (range, 0-228). The interval was 138 months (range, 0-228) in RCC patients, 154 months in a rectal cancer patient, and 5 months in a MM patient, respectively (Table 2). Pancreatic metastasis was solitary in 6 cases and multiple in 3 cases and existed in the head in 2 cases, in the body-tail in 6 cases, and in the whole pancreas in 1 (case no. 7). Interestingly, metastasis from the left kidney was developed in pancreatic body-tail in all cases (nos. 1, 3, and 5). The median size of the largest pancreatic metastasis was $28 \mathrm{~mm}$ (range, 10-39). In case no. 6 , whereas the pancreatic tumor was only $10 \mathrm{~mm}$ (Fig. 1a), it could be preoperatively diagnosed as metastasis from clear cell RCC by endoscopic ultrasound-guided fine needle aspiration (EUS-FNA) (Fig. 1b, c).

Operative procedure was distal pancreatectomy (DP) in 6 cases, pancreaticoduodenectomy (PD) in 2 cases (pylorus-preserving pancreaticoduodenectomy (PPPD) in 1 and subtotal stomach-preserving pancreaticoduodenectomy (SSPPD) in 1), and total pancreatectomy (TP) in 1 case (Table 2, Fig. 2a, b). Median operative time was $328 \mathrm{~min}$ (range, 241-472), and median operative blood loss was $580 \mathrm{~g}$ (range, 136-2587). Postoperative complication was observed in $3(33.3 \%)$, grade B of postoperative pancreatic fistula (POPF) in 2, and delayed gastric emptying (DGE) in 1. There was no

Table 2 Characteristics of the pancreatic metastasis and results of the pancreatic surgery

\begin{tabular}{|c|c|c|c|c|c|c|c|c|c|}
\hline $\begin{array}{l}\text { Case } \\
\text { no. }\end{array}$ & $\begin{array}{l}\text { Interval } \\
\text { (months) }\end{array}$ & Location & $\begin{array}{l}\text { Tumor } \\
\text { number }\end{array}$ & $\begin{array}{l}\text { Size } \\
(\mathrm{mm})\end{array}$ & $\begin{array}{l}\text { Operative } \\
\text { procedure }\end{array}$ & $\begin{array}{l}\text { Operative time } \\
\text { (min) }\end{array}$ & $\begin{array}{l}\text { Operative } \\
\text { bleeding (g) }\end{array}$ & $\begin{array}{l}\text { Postoperative } \\
\text { complication }\end{array}$ & Histology \\
\hline 1 & 60 & Tail & 2 & 14,25 & $\mathrm{DP}$ & 241 & 467 & None & Clear cell RCC \\
\hline 2 & 0 & Head & 1 & 36 & PPPD & 448 & 710 & DGE & Clear cell RCC \\
\hline 3 & 138 & Body-tail & 3 & $\begin{array}{l}17,22 \\
28\end{array}$ & DP & 299 & 580 & None & Clear cell RCC \\
\hline 4 & 156 & Body-tail & 1 & 30 & DP & 328 & 136 & None & Clear cell RCC \\
\hline 5 & 228 & Tail & 1 & 39 & $\mathrm{DP}$ & 440 & 2587 & None & Clear cell RCC \\
\hline 6 & 144 & Head & 1 & 10 & SSPPD & 472 & 745 & POPF & Clear cell RCC \\
\hline 7 & 26 & $\begin{array}{l}\text { Head- } \\
\text { body-tail }\end{array}$ & 6 & $6 \sim 20$ & $\mathrm{TP}$ & 406 & 1176 & None & Clear cell RCC \\
\hline 8 & 154 & Tail & 1 & 35 & DP & 324 & 445 & POPF & $\begin{array}{l}\text { Tubular } \\
\text { adenocarcinoma }\end{array}$ \\
\hline 9 & 5 & Body-tail & 1 & 28 & DP & 263 & 356 & None & $\begin{array}{l}\text { Malignant } \\
\text { melanoma }\end{array}$ \\
\hline
\end{tabular}

Interval months from the initial surgery to the operation for the pancreatic metastasis, DGE delayed gastric emptying, $D P$ distal pancreatectomy, $P O P F$ postoperative pancreatic fistula, PPPD pylorus-preserving pancreaticoduodenectomy, $R C C$ renal cell carcinoma, SSPPD subtotal stomach-preserving pancreaticoduodenectomy, TP total pancreatectomy 


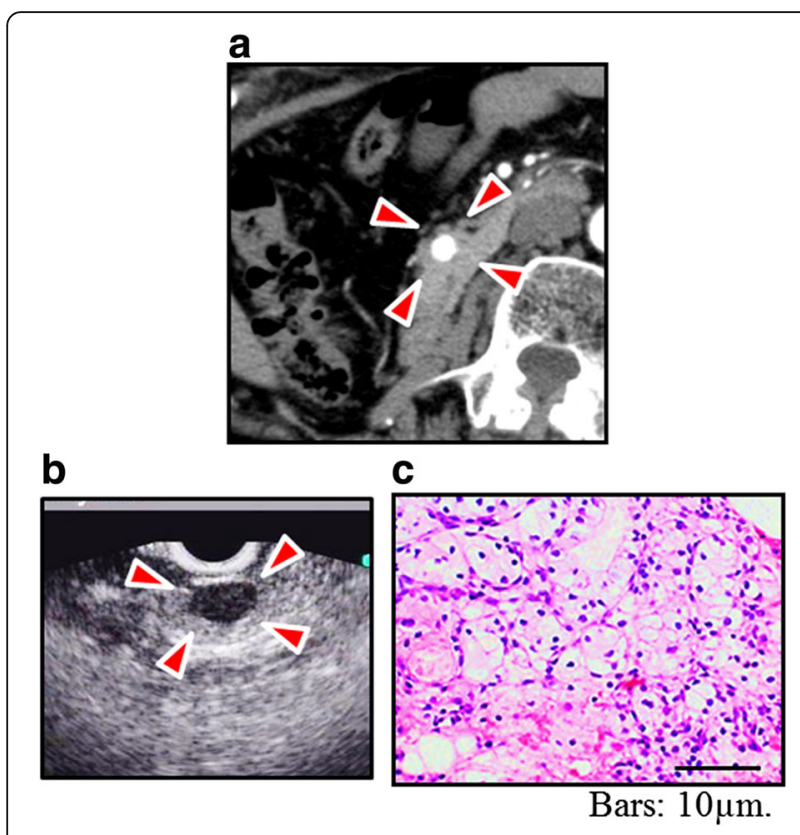

Fig. 1 Preoperative findings of case no. 6. Enhanced $C T$ (a) and EUS (b) revealed 10-mm tumor (arrowheads) in the pancreatic head of case no. 6. It was preoperatively diagnosed as metastasis from clear cell RCC (c) by EUS-FNA

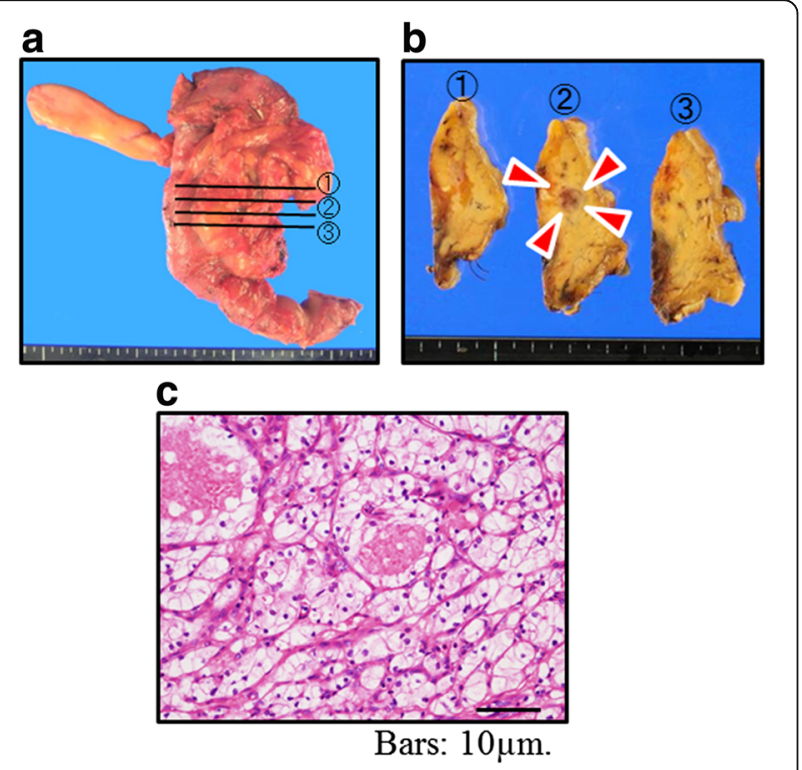

Fig. 2 Operative and histological findings of case no. 6. SSPPD (a) was performed in case no. 6. Histologically, the tumor (arrowheads) (b) was confirmed as the metastasis from clear cell RCC (c) hospital death. Pathological diagnoses of the pancreatic tumors were consistent with those of the primary lesion in all cases (Fig. 2c).

\section{Other metastasis after pancreatic metastasis and long- term outcome}

Bilateral multiple lung metastasis existed in 3 patients with metastasis from RCC, and 2 cases of them were treated by combination of interferon (IFN), interleukin-2 (IL-2), and tegafur-uracil (UFT) or sunitinib, respectively (Table 3). Bilateral multiple lung metastasis and bone metastasis developed in a patient with metastasis from MM, treated by dacarbazine.

Two patients with metastasis from RCC and 1 patient with metastasis from MM died 131, 108, and 4 months after the pancreatic resection, respectively. Other 6 patients have survived until now with 23.5 months (range, 3-138) of observation periods after pancreatic resection.

\section{Conclusions}

The pancreas is an unusual but occasionally favored site for metastasis, notably from carcinoma of the kidney and lung $[1-3,15]$. In this series of the patients, $77.8 \%$ (case nos. 1-7) pancreatic tumor were metastasis from clear cell RCC and $11.1 \%$ (case no. 7) were from rectal cancer, consistent with previous studies [4-7]. Interestingly, all metastatic tumors from the left RCC (3 cases) were developed in the left side of the pancreas. This tendency of metastatic direction to the pancreas has been never reported and may indicate the mechanism of hematogenous metastasis from the kidney to pancreas. In patients with portal hypertension, vascular endothelial growth factor (VEGF)-dependent angiogenesis plays a crucial role in the formation of portal-systemic collateral vessels, which include spleno-renal shunts [16]. VEGF has an important role in progression of RCC [17]. Collateral vessels like spleno-renal shunts dependent on VEGF angiogenesis possibly contribute to the tendency of metastatic direction in RCC patients. One case of our series was the metastasis from oral malignant melanoma, with poor prognosis even the aggressive chemotherapy by dacarbazine. There were a few reports indicated similar situation [18, 19]; however, it appears that surgical resection is only a palliative procedure, because long-term survival is a rare event.

Despite the technological advances, preoperative diagnosis of the metastatic pancreatic tumor is sometimes difficult [15]. EUS-FNA is an excellent method for procurement of diagnostic samples from the pancreas, with a diagnostic accuracy of more than $90 \%$ for pancreatic adenocarcinoma [20,21]. One patient in this study (case no. 6) was preoperatively diagnosed as metastasis of clear cell RCC by EUS-FNA, even only $10 \mathrm{~mm}$ of the size of the 
Table 3 Other metastasis after pancreatic metastasis and long-term outcome

\begin{tabular}{|c|c|c|c|}
\hline \multirow[t]{2}{*}{ Case no. } & \multicolumn{2}{|c|}{ Recurrence or metastasis after pancreatic resection } & \multirow{2}{*}{$\begin{array}{l}\text { Postoperative } \\
\text { observation } \\
\text { period } \\
\text { (months) }\end{array}$} \\
\hline & Location & Treatment & \\
\hline 1 & Bilateral lung & None (BSC) & $131^{\mathrm{a}}$ \\
\hline 2 & Bilateral lung & $\mathrm{IFN}+\mathrm{IL}-2+\mathrm{UFT}$ & $108^{\mathrm{a}}$ \\
\hline 3 & - & - & 138 \\
\hline 4 & - & - & 49 \\
\hline 5 & Bilateral lung & Sunitinib & 8 \\
\hline 6 & - & - & 8 \\
\hline 7 & - & - & 3 \\
\hline 8 & - & - & 39 \\
\hline 9 & Bilateral lung, bone & Dacarbazine & $4^{\mathrm{a}}$ \\
\hline
\end{tabular}

Postoperative observation period months after the operation for the pancreatic metastasis, BSC best supportive care, IFN interferon, IL-2 interleukin-2, UFT tegafur-uracil

${ }^{\mathrm{a} D e a d}$

tumor. It suggested that EUS-FNA is useful to correct diagnosis of metastatic pancreatic tumor.

Surgical resection of the metastatic tumor to the pancreas should be approached by carefully applying appropriate selection criteria, because of the substantial morbidity indicated in this series and a previous report [22]. On the other hand, a noteworthy finding in our series was a long interval from the initial surgery to the pancreatic metastasis and long survival after pancreatic resection. This was particularly the cases with clear cell RCC patients. Yuasa et al. reported that the median duration from diagnosis of RCC to pancreatic metastasis was 7.8 years (4.2-12.7 years) [23]. Consistent with the study, metastatic tumor of the pancreas from RCC is recurred in long-term interval in general in our series. Patients with isolated RCC metastasis to the pancreas, whether synchronous or metachronous, represent a selected group of patients with more indolent RCC [22]. In addition, new effective therapeutic strategy such as molecular target drug has been introduced to metastatic disease from clear cell RCC [24]. This advantage may provide the benefit of resection of the pancreatic metastasis even with metastatic lesions in other organs such as the lung, in selected cases with good response to the treatment, as indicated in our study.

We performed distal pancreatectomy in 6 cases, pancreaticoduodenectomy in 2 cases, and total pancreatectomy in 1 case. The surgical strategy for pancreatic metastatic tumor has not been established. Recently, limited or partial pancreatectomy has been performed, especially for disease which does not need lymph node dissection [25]. These preserving operations may be useful for patients with pancreatic metastasis from clear cell renal cell carcinoma.

In conclusion, the metastasis to the pancreas can be developed years after the initial surgery of the primary disease. EUS-FNA was suggested to be feasible for diagnosis and helpful to consider the indication of surgery. Long-term survival can be archived with pancreatic resection, especially in patients with pancreatic metastasis from clear cell RCC.

\section{Abbreviations \\ DGE: Delayed gastric emptying; DP: Distal pancreatectomy; EUS-FNA: Endoscopic ultrasound-guided fine needle aspiration; IFN: Interferon; IL-2: Interleukin-2; MM: Malignant melanoma; PD: Pancreaticoduodenectomy; POPF: Postoperative pancreatic fistula; PPPD: Pylorus-preserving pancreaticoduodenectomy; PR: Partial response; RCC: Renal cell carcinoma; SSPPD: Subtotal stomach-preserving pancreaticoduodenectomy; TP: Total pancreatectomy; UFT: Tegafur-uracil}

\section{Acknowledgements}

No funding was received for this study.

\section{Authors' contributions}

TY carried out the acquisition of data and drafted the manuscript. DH was involved in drafting the manuscript. KT, KY, and AC carried out the acquisition of data. $\mathrm{MO}, \mathrm{TB}$, and $\mathrm{HB}$ have given the final approval of the version to be published. All authors read and approved the final manuscript.

Competing interests

The authors declare that they have no competing interests.

\section{Consent for publication}

Written informed consent was obtained from the patient for publication of this case report and any accompanying images. A copy of the written consent is available for review by the Editor-in-Chief of this journal.

\section{Author details}

'Department of Gastroenterological Surgery, Kumamoto University Graduate School of Medical Sciences, 1-1-1 Honjo, Kumamoto City 860-8556, Japan.

${ }^{2}$ Department of Gastroenterological Surgery, Institute of Resource Development and Analysis, Kumamoto University Graduate School of Medical Sciences, Kumamoto City, Japan. 
Received: 21 March 2016 Accepted: 15 February 2017

Published online: 18 February 2017

\section{References}

1. Dar FS, Mukherjee $S$, Bhattacharya S. Surgery for secondary tumors of the pancreas. HPB (Oxford). 2008;10:498-500.

2. Nakeeb A, Lillemoe KD, Cameron JL. The role of pancreaticoduodenectomy for locally recurrent or metastatic carcinoma to the periampullary region. $J$ Am Coll Surg. 1995;180:188-92.

3. Moussa A, Mitry E, Hammel P, Sauvanet A, Nassif T, Palazzo L, Malka D, Delchier JC, Buffet C, Chaussade S, Aparicio T, Lasser P, Rougier P, Lesur G. Pancreatic metastases: a multicentric study of 22 patients. Gastroenterol Clin Biol. 2004;28:872-6.

4. Balcom JH, Rattner DW, Warshaw AL, Chang Y, Fernandez-del CC. Ten-year experience with 733 pancreatic resections: changing indications, older patients, and decreasing length of hospitalization. Arch Surg. 2001;136:391-8.

5. Adsay NV, Andea A, Basturk O, Kilinc N, Nassar H, Cheng JD. Secondary tumors of the pancreas: an analysis of a surgical and autopsy database and review of the literature. Virchows Arch. 2004:444:527-35.

6. Sperti C, Pasquali C, Liessi G, Pinciroli L, Decet G, Pedrazzoli S. Pancreatic resection for metastatic tumors to the pancreas. J Surg Oncol. 2003:83:161-6. discussion 1 .

7. Roland CF, van Heerden JA. Nonpancreatic primary tumors with metastasis to the pancreas. Surg Gynecol Obstet. 1989;168:345-7.

8. Faure JP, Tuech JJ, Richer JP, Pessaux P, Arnaud JP, Carretier M. Pancreatic metastasis of renal cell carcinoma: presentation, treatment and survival. J Urol. 2001;165:20-2.

9. Palmowski M, Hacke N, Satzl S, Klauss M, Wente MN, Neukamm M, Kleeff J, Hallscheidt P. Metastasis to the pancreas: characterization by morphology and contrast enhancement features on CT and MRI. Pancreatology. 2008;8:199-203.

10. Z'graggen K, Fernández-del Castillo C, Rattner DW, Sigala H, Warshaw AL. Metastases to the pancreas and their surgical extirpation. Arch Surg. 1998:133:413-7. discussion 4

11. Sohn TA, Yeo CJ, Cameron JL, Nakeeb A, Lillemoe KD. Renal cell carcinoma metastatic to the pancreas: results of surgical management. J Gastrointest Surg. 2001;5:346-51.

12. Wente $M N$, Bergmann F, Fröhlich BE, Schirmacher $P$, Büchler MW, Friess $H$ Pancreatic metastasis from gastric carcinoma: a case report. World J Surg Oncol. 2004;2:43.

13. Lee CW, Wu RC, Hsu JT, Yeh CN, Yeh TS, Hwang TL, Jan YY, Chen MF. Isolated pancreatic metastasis from rectal cancer: a case report and review of literature. World J Surg Oncol. 2010;8:26.

14. Hiotis SP, Klimstra DS, Conlon KC, Brennan MF. Results after pancreatic resection for metastatic lesions. Ann Surg Oncol. 2002;9:675-9.

15. You DD, Choi DW, Choi SH, Heo JS, Kim WS, Ho CY, Lee HG. Surgical resection of metastasis to the pancreas. J Korean Surg Soc. 2011:80:278-82.

16. Tarantino G, Citro V, Conca P, Riccio A, Tarantino M, Capone D, Cirillo M, Lobello R, laccarino $\mathrm{V}$. What are the implications of the spontaneous spleno-renal shunts in liver cirrhosis? BMC Gastroenterol. 2009;9:89.

17. Bianconi M, Faloppi L, Loretelli C, Zizzi A, Giampieri R, Bittoni A, Andrikou K, Del Prete M, Burattini L, Montironi R, Scartozzi M, Cascinu S. Angiogenesis genotyping in the selection of first-line treatment with either sunitinib or pazopanib for advanced renal cell carcinoma. Oncotarget. 2016 May 9. doi: 10.18632/oncotarget.9229. [Epub ahead of print]

18. Sugimoto M, Gotohda N, Kato Y, Takahashi S, Kinoshita T, Shibasaki H, Kojima M, Ochiai A, Zenda S, Akimoto T, Konishi M. Pancreatic resection for metastatic melanoma originating from the nasal cavity: a case report and literature review. Anticancer Res. 2013:33:567-73.

19. Sperti C, Polizzi ML, Beltrame V, Moro M, Pedrazzoli S. Pancreatic resection for metastatic melanoma. Case report and review of the literature. J Gastrointest Cancer. 2011:42:302-6.

20. Yoshinaga S, Suzuki H, Oda I, Saito Y. Role of endoscopic ultrasound-guided fine needle aspiration (EUS-FNA) for diagnosis of solid pancreatic masses. Dig Endosc. 2011;23 Suppl 1:29-33.

21. Itoi T, Tsuchiya T, Itokawa F, Sofuni A, Kurihara T, Tsuji S, Ikeuchi N. Histological diagnosis by EUS-guided fine-needle aspiration biopsy in pancreatic solid masses without on-site cytopathologist: a single-center experience. Dig Endosc. 2011;23 Suppl 1:34-8.
22. Zerbi A, Ortolano E, Balzano G, Borri A, Beneduce AA, Di Carlo V. Pancreatic metastasis from renal cell carcinoma: which patients benefit from surgical resection? Ann Surg Oncol. 2008;15:1161-8.

23. Yuasa T, Inoshita N, Saiura A, Yamamoto S, Urakami S, Masuda H, Fujii Y, Fukui I, Ishikawa Y, Yonese J. Clinical outcome of patients with pancreatic metastases from renal cell cancer. BMC Cancer. 2015;15:46.

24. Mihaly Z, Sztupinszki Z, Surowiak P, Gyorffy B. A comprehensive overview of targeted therapy in metastatic renal cell carcinoma. Curr Cancer Drug Targets. 2012;12:857-72.

25. Kitasato A, Tajima Y, Kuroki T, Tsutsumi R, Tsuneoka N, Adachi T, Mishima T, Kanematsu T. Limited pancreatectomy for metastatic pancreatic tumors from renal cell carcinoma. Hepatogastroenterology. 2010;57:354-7.

\section{Submit your manuscript to a SpringerOpen ${ }^{\circ}$ journal and benefit from:}

- Convenient online submission

- Rigorous peer review

- Immediate publication on acceptance

- Open access: articles freely available online

- High visibility within the field

- Retaining the copyright to your article

Submit your next manuscript at $>$ springeropen.com 